\title{
Bedenleşme ve Enaksiyon Teorilerinin Çağdaş Tiyatro Uygulamalarına Yansımaları: Oyunculuk Eğitiminde Somatik Yaklaşım*
}

\section{Reflections of Embodiment and Enaction Theories on Contemporary Theater Practices: Somatic Approach in Acting Training}

\author{
Bilge Serdar Göksülük ${ }^{1}$ [D
}

"Bu makale 2020 yılında Ankara Üniversitesi Sosyal Bilimler Enstitüsü Tiyatro Anabilim Dalı́nda tamamladığım "Tiyatro ve Performans Sanatlarında Bilișsel Kırılma: Yeni Beden Fenomeni 'Soma' ve Enaktif Oyunculuk Teorilerine Doğru Hareket Odaklı Bir Eğitim Önerisi Olarak Somatik Yaklaşım" başılıkı doktora tezinden hareketle hazırlanmıștır.

'Dr. Ankara Üniversitesi, Dil ve Tarih-Coğrafya Fakültesi, Tiyatro Bölümü, Ankara, Türkiye

\section{ORCID: B.S.G. 0000-0001-8580-5964}

Sorumlu yazar/Corresponding author: Dr. Bilge Serdar Göksülük, Ankara Üniversitesi, Dil ve Tarih-Coğrafya Fakültesi, Tiyatro Bölümü, Ankara, Türkiye E-posta/E-mail: bilge.serdar@gmail.com

Başvuru/Submitted: 02.04 .2021 Revizyon Talebi/Revision Requested: 11.04.2021

Son Revizyon/Last Revision Received: 11.04.2021

Kabul/Accepted: 07.05 .2021

\section{Atıf/Citation:}

Göksülük, Bilge Serdar. "Bedenleşme ve Enaksiyon Teorilerinin Çağdaş Tiyatro Uygulamalarına Yansımaları: Oyunculuk Eğitiminde Somatik Yaklaşım" Tiyatro Eleştirmenliğive Dramaturji Bölümü Dergisi 32, (2021): 145-168 https://doi.org/10.26650/jtcd.908412 öz

Yirmi birinci yüzyılda bilişsel bilimler, sinirbilimleri ve fenomenolojinin ortaklığında gelişen enaksiyon teorileri, doğrudan tiyatro ve performans sanatları alanına giren imgelem, algı, duygu, his ve düşünce gibi bilişsel süreçlere ilişkin kavrayışımızı değiştirir. Enaksiyon teorileriyle anlamlandırma süreçlerinde bedensel eylemliliğe yapılan vurgu, kişinin birincil hareket deneyimini anahtar kavram haline getirir. Bu çalışmada da tiyatro ve performans alanında bu kavrayış değişikliğinin izi teorik olarak sürülerek, bedenleşmiş bilinç kavramı tartışmaya açılır. Bu bağlamda hareket deneyimi üzerine öz-gözlemsel bir uygulama alanı olan somatik uygulamaların bedenleşmiş bir deneyimi nasıl sağladığı ve böylelikle oyunculuk eğitimine nasıl katkı sağlayabileceği üzerinde durulur. Özetle, bu makalenin temel amacı bedenleşme teorilerinden kısaca bahsederek olası tartışma alanlarına işaret etmek ve somatik uygulamaların oyunculuk eğitimine nasıl katkı sunabileceğini tartışmaktır.

Anahtar Kelimeler: Bedenleşme, Enaksiyon, Somatik yaklaşım, Performatif beden bilinci, Oyunculuk eğitimi

\section{ABSTRACT}

In the 21 st century, enaction theories that have emerged as a result of the intersection of neuroscience, cognitive science, and phenomenology have changed our understanding of cognitive processes, such as imagination, perception, feeling, emotion, and thought, which are directly related to theater and performing arts. In enaction theories, the emphasis on bodily action in the process of providing meaning makes one's primary movement experience a key concept. The study thus traces such theoretical shift in theater and performing arts and discusses the concept of embodied consciousness that expectedly occurs during the performance. Furthermore, based on embodiment theories, the study elucidates how somatic practices provide an embodied experience that facilitates performative awareness and how such practices contribute to actor training. Briefly, the main objectives of this study are to highlight possible discussions and emphasize the contribution of somatic practices in actor training based on embodied theories.

Keywords: Embodiment, Enaction, Somatic Approach, Performative body consciousness, Actor training 


\section{EXTENDED ABSTRACT}

Embodiment suggests that one's experience of the world is a result of the interaction between one's bodily qualities and their environment (social, cultural, economic, and natural conditions). Therefore, cognitive processes, such as meaning, imagination, thought, and language, which are abstract concepts, cannot be separately understood from bodily experience and metaphysical qualities; however, they are considered as results of one's changing activities, which are dependent on their environmental conditions. Accordingly, various theories, such as embodied mind, meaning, and reality, have emerged. Moreover, the enaction theory focuses on the interaction between perception and action, which includes embodied theories, and emphasizes that one's mutual interaction with their environment occurs through one's agency. In this sense, the concept of enactive embodiment expands the limit of the word embodiment, which is usually discussed in terms of the tension between the actor's own body and the character in theater and performing arts. In enactive theories, "action" becomes the activating force of consciousness and "movement" becomes the constitutive element of meaning. This aspect reveals the subconscious bodily foundations of meaning apart from linguistics. The purposes of this study are to highlight such shift in bodily phenomena and discuss the need for a somatic approach in actor training.

In terms of actor training, the most crucial aspect of scientific discourse is to emphasize that a well-directed self-reflection on one's personal experience of movement plays an essential role in developing rich insight about others, increasing empathy skills, and strengthening intuitions. Hence, in the context of theater and performing arts education, a phenomenological self-reflective monitoring of one's personal experience is the way through which the experience can be opened as a learning space wherein senses can be refined, new questions and answers emerge, and any technique can be personalized, which corresponds to a "conscious experience." Thus, conscious experience should be understood as a state of being and not as a state of continuous questioning.

Movement means that the moving person can visually or tactically perceive and can kinesthetically feel their own movements; in other words, movement is treated as a field of discovery wherein one can directly experience the "internal" and "external" realms through their own movements. In addition, somatic practices are widely spreading in art education worldwide in recent years. They offer the actor an opportunity to practice a phenomenology of movement. This characteristic of somatic practices differs from the investigation of different forms and situations of the phenomenon using the imagination that is observed in Husserl's eidetic variation. In phenomenological study through the execution of movement, one may discover the relationship between the function and expressiveness of one's own movements through one's intention. This aspect indicates that during the execution of movement, as the 
intention changes (the intention may focus on effort, the shape of the body, a point in space, power, etc.), one realizes the changes depending on the changed intention. During all these activities, the body's scheme is examined through developmental movement patterns, and as a result, a body image is developed. Accordingly, somatic studies improve reflective and pre-reflective bodily consciousness by developing the senses of proprioception, kinesthesia, and interoception. Therefore, somatic movement practices help performers to exhibit a truly embodied acting on stage and achieve performative awareness, that is, a special heightened state of consciousness that occurs in the performance of actors, such as dancers, athletes, or musicians.

Somatic practices pertain to training the behavioral sensory and perceptual sensitivity. The actor gets an embodied experience through somatic practices by discovering the connection between action and intention, physical and emotional states, and function and expression through their own experience. Such an experience constitutes the first step of embodied acting on stage. Therefore, this study highlights the need for a somatic approach as a base of actor training to facilitate the understanding of embodied theories from a scientific perspective. 


\section{Giriş: 21. Yüzyıl Tiyatrosunda Yeni İhtiyaçlar}

İçinde yaşadığımız yirmi birinci yüzyılda, kendi otonomisini kurabilen yapay zihinlerin üretiminin tartışıldığı, yerimizden dahi kalkmadan dünyanın öteki ucundan sipariş vererek ihtiyaçlarımızı karşılayabildiğimiz, istediğimiz becerileri yükleyerek kurgusal bir dünyada avatarlarımızı yani alternatif kimliklerimizi yaratabildiğimiz, gerçek anlamda zaman, mekan ve ağırlık deneyiminin neredeyse tamamen ortadan kalktığı sanal bir gerçeklikle karşı karşıyayız. Bu gelişmelerle beden, bir yandan deneyimsel alandan gittikçe geri plana itilip silikleşirken, bir yandan da tıptaki gelişmeler, bedene yapılabilecek müdahalelerin sınırlarını genişleterek bedeni, işlevselliğini bozmadan, istenilen görüntünün sağlanabileceği bir vitrin haline getirir. Her iki durumda da aslında söz konusu olan bir "bedensizleşme" dir. İlk durumda sanal ortamda bütün bir dünya deneyimi baskın bir biçimde çoğunlukla görme duyusunun ve işitme duyusunun öncülük ettiği bedensel olarak indirgenmiş bir deneyime dönüşür. İkinci durumda da beden, kendilik kurulumunun daha çok sembolik, dışsal bir öğesi olarak öne çıkar. İronik bir biçimde sinirbilimleri ve bilişsel bilimlerin sonuçları ise her geçen gün insanın bilişsel işlevlerinin kaynağı olarak bedenliliğimizi ortaya koyar ve bedenleşme teorileri güncel düşünme pratiklerini belirler. Bedensizleşmenin hüküm sürdüğü bir çağda bedenleşme teorilerinin güçlenmesinin yarattığı paradoks, Arran Gare gibi eko-felsefeciler tarafindan bu çağın "Yeniden Bedenleşme Çağı (The Age of Reembodiement)"” olarak isimlendirilmesine yol açar. Bu anlamıla bedenleşme, bedenli varlıklar olarak bu dünyadaki ikametimiz sırasında baskın teori ve söylemlerin ötesinde tüm anlamlandırma süreçlerini ve ürettiğimiz değerlerin tümünün gözden geçirilmesini gerektirir. $\mathrm{Bu}$ da aslında kendi deneyimimize dönüş çağrısıdır. $\mathrm{Bu}$ anlamda deneyim kabaca sadece bir yaşanmışlık değil, bilgi birikiminin olduğu bir öğrenme ve karşılıklı etkileşimlerle hem kişiliğin hem kültürün kurulduğu bir üretim alanıdır. ${ }^{3}$ Aslında kendi bedenliliğimizi unuttuğumuz bir dönemde bize bedenleşmeyi hatırlatan bir bilimsel söylemin ortaya çıkışı da fenomenolojinin yani birincil deneyimin bilimsel dünyaya sızmasıyla ortaya çıkan enaktif teorilerle birlikte gerçekleşir. Enaktif teorilerde bedenleşme en temelde düşünme, dil, imgelem, karar alma, yaratıc1lık gibi tüm bilişsel süreçlerin, bedenin eylemliliği yoluyla çevreyle etkileşiminin bir sonucu olarak ortaya çıktığını ve kişinin birincil deneyimini dışarıda bırakan bir bilim, sanat, eğitim ve hatta felsefenin temel iddiası olan insanı anlamaya yaklaşamayacağını ortaya koyar.

Bedenleşme teorileri bir yandan bedenleşmiş gerçeklik (embodied realism), bedenleşmiş bilinç (embodied cognition), bedenleşmiş zihin (embodied mind), bedenleşmiş anlam (embodied

1 Arren Gare, "The Grand Narrative Of The Age Of Reembodiments: Beyond Modernism And Postmodernism" Cosmos and History: The Journal of Natural and Social Philosophy 9/1 (2013), 327-357.

2 A.g.e.

3 Bkz. Martin Jay, Deneyim Şarkıları, çev: Barış Engin Aksoy (İstanbul: Metis,2012), Peirce, C. S., James, W., \& Dewey, J., Felsefenin Yeniden Yapılandırllması, Pragmatizm: Pratik Bir Felsefe Seçme Yazılar,çev. ve Ed: Sarah Çelik, (İstanbul: Doruk Yayımcılık, 2018). 
meaning) gibi yeni kategoriler yaratırken bir yandan da yukarıda da değinildiği gibi imgelem, karar alma, duygu, his gibi süreçlerin duyu-motor sistemle ilişkisini ortaya koyar. Bu da yaratıcı süreçle doğrudan ilişkili olan bu kavramlarda kırılmalar yaratarak çağdaş tiyatro alanında ortaya çıkan yönetmenin ve oyuncunun nosyonunda, oyunculuk eğitimi pratiklerinde ve de yaratım süreçlerindeki değişimlere teorik bir zemin sunar. Bedenleşme (embodiment) tıpkı Erica Fischer-Lichte'nin de ifade ettiği gibi bir estetik argüman haline gelir ve tiyatro ve performans sanatları bağlamında öncelikli olarak "bedenin bir nesne, konu, tema, sembol oluşturmak için bir kaynak" ve "kültürel izlerin bir ürünü" olarak ele alınmasını ifade eder. ${ }^{4} \mathrm{Bu}$ anlamda bedenleşme kavramının tiyatro uygulamalarındaki ve teorisindeki karşılı̆̆ Lichte için "metinden" ve "temsilden” bedene doğru bir kaymaya denk düşer. Jen Harvie ise Making Contemporary Theater: International Rehearsal Processes adlı kitabında günümüzde süregelen teatral yönelimleri “yönetmenin ve metnin rolünün sorgulanması, kolektif üretim, her şeyden önce yaratım sürecinin etiğine ve dinamiklerine öz-düşünümsel dikkat"5 olarak sıralar. Lehmann ise Postdramatic Theatre adlı kitabında postdramatik tiyatronun bazı niteliklerini "temsilden çok mevcudiyet, paylaşımdan çok karşılıklı iletişimin sağlandığı bir deneyim, üründen çok süreç, imlemekten/belirli bir anlama işaret etmekten çok manifesto, bilgiden çok enerjik bir uyarıc1"6 olarak tarif eder. Aslında Lehmann'1n, Harvie'nin ve Fischer-Lichte'nin örtüşen bu ifadeleri çağdaş tiyatro pratiklerinde bedenin değişen konumunun yanı sıra diğer iki önemli özelliğine de işaret eder: bir yaratım süreci olarak prova süreçlerinin önemi ve de metnin ve yönetmenin sorgusuz üstünlüğ̈nün altının oyulması. Bu, temelde performansın estetik yönünü belirleyen şeyin artık sadece metin ya da yönetmen olmadığı anlamına gelir. Artık performansın estetik karakterini belirleyen şey tüm prova süresince herkesin, tüm faillerin (yazar, yönetmen, oyuncu, sahne tasarımcısı, asistan vs.) katılımını gerektiren Harvie'nın de ifade ettiği gibi "yaratım sürecinin niteliğidir"” ki bu nitelik katılımcıların yanı sıra prova mekanı ve çalışma koşulları gibi çevresel şartlar tarafından da belirlenir.

Bunun yanı sıra çağdaş tiyatroda oyuncunun pozisyonu da farklılaşır. Lehmann, modernizimden önceki tiyatro uygulamalarında önce oyuncunun bedeninin bir gösteren olarak disipline edildiğini, eğitildiğini ve ona biçim verildiğini ancak otonom bir problem olarak ya da dramatik tiyatronun bir teması olarak ele alınmadığını dile getirir. Lehmann'a göre modern tiyatro ve post-modern tiyatro, oyuncunun bedeninin yeni potansiyellerini, en temelde bu semantik bedenin üstesinden gelerek geliştirebilmiştir. ${ }^{8} \mathrm{Bu}$ durumda oyuncudan istenen artık Lehmann'ın da belirttiği gibi kendini sunmasıdır, sadece bir şeyi ya da kimseyi temsil etmesi değil, sahnede mevcut olmasıdır. Yaratım sürecinde oyuncunun kendine özgü

4 Erica Fischer-Lichte, Performatif Estetik, çev:Tufan Acil (İstanbul: Ayrıntı, 2004), 153.

5 Jen Harvie, Making Contemporary Theatre: International Rehearsal Processes, Manchester: Manchester Universty Press, 2010).

6 Hans-Thies Lehmann, Postdramatic Theatre, çev: Karen Jürs-Munby (NY: Routledge,2006), 85.

7 Harvie, Making Contemporary Theatre: International Rehearsal Processes.

8 Lehmann, Postdramatic Theatre 162. 
kişiliği karakterden daha önemli hale gelir. Başka bir deyişle sahnede oyuncunun "otantikliği”" öne çıkar. Lehmann'ın Valère Novarina'dan aktardığg gibi artık “oyuncu yorumcu değildir, çünkü beden bir enstrüman değildir" ". Bu durumda yönetmen ya da eğitmen için de yeni bir misyon belirmiş olur. Yönetmen prova süresince ya da eğitmen eğitim boyunca oyuncuyu bir karakterin yorumcusu ya da temsilcisi olarak değil, bir yaratıcı olarak yönlendirip kanalize edebilmelidir. Harvie yönetmenin bu yeni nosyonunu "kolaylaştırıcı (facilitator) olarak yönetmen"10 şeklinde tanımlar. O zaman hem kolaylaştırıcı olarak bir yönetmenden hem de kolaylaştırıcı olarak bir eğitmenden beklenen yaratıcılığı kışkırtmak ve oyuncuyu yaratımın işbirlikçisi olarak sürece dahil etmek için olanak sağlamaktır.

Yukarıda tarif edilen çağdaş tiyatro uygulamalarında performansın estetik niteliğini belirleyen yaratım süreci, oyuncunun kendiliği ve tüm bunları koordine edecek bir eğitmen ya da yönetmen nosyonu, 17. yüzyıldan kalma Kartezyen dünya tasavvurunun ${ }^{11}$ mirası olan, birbirinden keskin sınırlarla ayrılan bilim anlayışıyla; bedeni zihinden, özneyi nesneden, doğayı kültürden, duyguyu akıldan ayrı tutan Kartezyen düalist görüşle ve de bu görüşün sızdığı tüm kavram ve teorilerle tartışmak yeterli olmaz. Son yıllarda performans sanatları eğitiminde (özellikle de dans eğitiminde) sıklıkla kullanılan Feldenkrais, Laban/Bartenieff, Alexander tekniği gibi somatik uygulamaların yaygınlaşması Kartezyen kategorilerin dişına çıkma çabası olarak görülebilir. Bu nedenle tüm bu gelişmelerin yaratıcı süreçlere sızarak tiyatro ve performans sanatları alanını kışkırtması ve de kuramsal tartışmalara yön verebilmesi için bedenleşme teorilerine ve alana yansımalarına yakından bakmak gerekir. Bu amaçla makale, teorik bir zemin sunması açısından bedenleşme teorilerinin beden fenomeninde yarattığ somatik olana doğru kaymaya odaklanarak başlar. Daha sonra somatik eğitimin genel özellikleri ve somatik pratiklerin içeriği oyunculuk çalışmaları da göz önünde bulundurularak ayrıntılandırılır. Son olarak da somatik hareket eğitiminin bedenleşmiş bir oyunculuğu nasıl sağlayacağı, birbirinden ayrı beden farkındalığı türleri yoluyla tartışılır. Genel itibariyle makale pratikle teoriyi birlikte ele alsa da aslında somatik pratiklerin nasıl işlediğini ve oyunculuk eğitiminde neden gerekli olduğunu bilimsel verilerden yola çıkarak açıklamaya, tartışmaya çalışır. Bu nedenle odağında uygulama önerilerinden çok teorik tartışmalar yer alır.

\section{Bedenleşme Teorileri ve Yeni Beden Fenomeni Soma}

20. yüzyılın özellikle ikinci yarısından itibaren fenomenoloji ve bilişsel bilimlerin yakınlaşması Batı düşünce geleneğinde bedenleşme teorilerinin yaygınlık kazanmasına dolayısıyla da beşeri bilimlerle fen bilimleri arasındaki keskin ayrımların belirsizleşmesine yol açtı. Bu nedenle tiyatro araştırmalarında çoğunlukla oyuncunun oynadığı karakter ve

9 A.g.e, 163.

10 Harvie, Making Contemporary Theatre: International Rehearsal Processes, 12.

11 Kartezyen dünya tasavvuru için bkz. Tülin Bumin, Tartışılan Modernlik: Descartes ve Spinoza (İstanbul:YKY, 2019); Descartes, Meditasyonlar: Metafizik Üzerine Düşünceler, çev. Çiğdem Dürüşken (İstanbul: Alfa 2019). 
kendi bedeni arasındaki gerilimli ilişkinin niteliğini tanımlamak üzere kullanılan bedenleşme kavramını daha geniş perspektifle ele almak, oyunculuk eğitimlerinde somatik beden (yaşayan, çok boyutlu bütüncül beden) anlayışına doğru yaşanan kaymayı anlamak için önemlidir. 1990'ların başında bu paradigma değişimine öncülük eden en önemli çalışmalardan biri Francisco J. Varela, Evan Thompson, Eleanor Rosch, The Embodied Mind: Cognitive Science and Human Experience ${ }^{12}$ adlı çalışma oldu. Varela, Thompson ve Rosch, Husserl ve MerleauPonty'nin fenomenoloji anlayışını miras alarak bilimsel çalışmaların birinci elden yaşayan insan deneyiminden bağımsız düşünülemeyeceğini savundular. Hatırlanacağı üzere fenomenolojik gelenekte bedenin öznel ve nesnel boyutu başka bir deyişle fiziksel yapısı ile deneyimsel niteliği ya da içi ile dışı birbirinin karşısında konumlanmaz, öznel olanla nesnel olan birlikte kurulur. Fenomenolojik bağlamda bedenleşme (embodiment) de bu nedenle Merleau-Ponty'nin ifade ettiği gibi bedeni hem yaşayan deneyimsel bir yapı olarak hem de bilişsel mekanizmanın bağlamı ya da ortamı olarak çift yönlü olarak kavrar. ${ }^{13}$ Buna göre bedenleşme (embodiment) kavramı Verala-Thompson ve Rosch için iki noktayı vurgular: ilk olarak bilinç, çeşitli duyumotor kapasiteleri olan bir bedene sahip olması dolayısıyla bir takım deneyimlere bağlıdır, ikinci olarak da bu bireysel duyu-motor kapasiteler olası biyolojik, psikolojik ve kültürel bağlamlara gömülüdür. Burada "aksiyon (eylem)" terimi özellikle önemlidir çünkü duyu ve motor süreçler (yani algı ve eylem), yaşayan bilinçten ayrılamaz ${ }^{14}$. Bu bağlamda Verala-Thompson ve Rosch “enaksiyon” (enaction) ${ }^{15 *}$ teorisini bedenleşme ve aksiyon kavramlarının karşılıklı etkileşiminden yola çıkarak algının doğası ve eylemin algıya nasıl dahil olduğunu araştıran bir alan olarak tanımlar. ${ }^{16}$ Bugün dilbilim, felsefe, psikoloji gibi disiplinlerde bedenleşmeyi odağa alan pek çok çalışma enaksiyon teorileri altında kendine yer bulur.

Deneyim yoluyla bilincin (ve tüm bilişsel işlevlerin: anlama, hayal gücü, hafiza, dil, his vs.) kaynağının bedenin içinde bulunduğu çevreyle etkileşiminde yani insanın eylemliliğinde olduğunu vurgulayan enaksiyon teorilerinin bedenleşmeye yaptığ 1 vurgu birbiriyle iç içe geçmiş birtakım sonuçlar doğurur. Johnson, The Meaning of the Body: Aesthetics of Human Understanding ${ }^{17}$ kitabında bilinci bedenleşmiş olarak ele almanın sonuçlarını şöyle özetler: İlk olarak "radikal bir zihin/beden ayrımı yoktur". Yani insan, zihin ve beden denen iki farklı ontolojik yapının bir bileşimi değildir. İkinci olarak "anlam da bedensel deneyimde

12 Francisco Varela, Eleanor Rosch ve Evan Thompson, The Embodied Mind: Cognitive Science and Human Experience. Massachusetts: MIT Press. 1991.

13 Merleau-Ponty, Algının Fenomenolojisi, çev: Emine Sarıkartal, Eylem Hacımuratoğlu (İstanbul: İthaki,2016).

14 Varela, Rosch, ve Thompson. The Embodied Mind: Cognitive Science and Human Experience, 173

15 * İngilizce'deki yasallaştırma, kanunla düzenleme ya da canlandırma, sahneleme anlamlarına gelen "to enact" fiilinden türetilen enaction kelimesi, Fransio G. Varela ve Humberto R. Maturana'nın Bilgi Ağacı kitabı çevirisinde Mahir Ünsal Eriş tarafından "varlık kazandıran” olarak çevirilmiştir. Ancak enaction terimi "varlık kazandıran" olarak kavramsallaştırıldığında, içinde barındırdığg "aksiyon" vurgusu kaybolur. Bu nedenle bu tez boyunca enaction kavramı için doğrudan enaksiyon teriminin kullanılması uygun görülmüştür.

16 Varela, Rosch, ve Thompson. The Embodied Mind: Cognitive Science and Human Experience,173.

17 Mark Johnson, The Meaning of the Body: Aesthetics of Human Understanding (Chicago: University of Chicago Press:2007). 
temellenmiştir”. Bedenden ayrılmış bir zihin söz konusu değildir ki bu aşkın bir ruh ya da ego olmadığı anlamına gelir. Bunun yanı sıra “akıl somut ya da soyut bir şey değildir”, keşfetme, eleştirme ve dönüştürme deneyimimiz yoluyla bedenleşmiş bir süreçtir. En önemlisi de "hayal gücü, imgelem bedensel süreçlerimizle ilişkilidir ve deneyimin dönüştürücüsü ve yaratıcısı olabilir”. "Radikal bir özgürlük yoktur". Bu da "ben" olarak kavranan şeyin ancak var olan bedenin çevreyle etkileşiminin bir sonucu olarak "ben" olduğu anlamına gelir. Akıl/duygu ikiliği her yerde karşımıza çıkan temel bir metafiziksel ikilik olmasına rağmen "akıl ve duygu ayrılmaz bir biçimde iç içedir” ve duygular kavramsallaştırma, akıl ve imgelem gibi bilişsel kapasitelerimizin temellerinde yatar. Tüm bunların sonucu olarak da bedenleşme teorileri ruh ya da tin olarak kabul edilen şeyin aşkın bir kavram olmadığını gösterir yani “insanın tinselliği (ruhaniliği) de bedenleşmiştir". ${ }^{18}$

Johnson'ın sonuçlarını özetlediği bedenleşme teorilerine dayanan bu çalışmalar, tiyatro ve performans alanı açısından birbiriyle ilişkili üç önemli kavramı tartışmaya açar: bir kurucu öğe olarak "hareket", bir araştırma alanı olarak "birincil deneyim” ve bütüncül bir beden anlayışı yani "soma". İlk olarak enaksiyon teorileri kapsamındaki sinirbilimsel ve bilişsel bilimler alanındaki çalışmaların sonuçları yukarıda da söz edildiği gibi anlamın dilde başlamadığını, çok daha öncesinde bilinç dışı düzeyde bedenimizin dünyayla kurduğu ilk iletişimle ortaya çıktığını ortaya koyar ki bu ilk iletişimin koşulu ilksel harekettir ${ }^{19}$. Enaksiyon teorisi kısaca "bilincin algıdan, algının hareketten, hareketin bir çevreden ve davranış olarak tasarlanan daha büyük bir kategoriden ayrı olmadığı" ${ }^{20}$ sonucunu verir bize. Yani anlam arayışında hareket ön koşuldur. Enaksiyon teorileri bağlamında öne çıkan hareket Husserl'ci anlamda bir harekettir yani kişinin içsel olanla dışsal olanı kendi hareketinde birlikte deneyimlediği bir alandır. $\mathrm{Bu}$ nedenle hareket, konvansiyonel oyunculuk çalışmalarındaki gibi içeriden-dışarı, dışarıdaniçeri geçişin bir aracı olarak yani duygudan harekete, hareketten-duyguya yaklaşımıyla ele alınmaz. Hareket, değişimi ve dönüşümü içeren, zamanda ve mekanda oluşurken aynı zamanda kendi mekanını ve zamanını yaratan dinamik bir fenomen olarak kavranır. Başka bir deyişle hareket kişinin hem -dışsal olana referansla- üç boyutlu olarak algıladığı hem de -içsel olana referansla- hissedebildiği bir oyun alanıdır.

İkinci önemli nokta tüm bu bilimsel çalışmaların yöntemlerine ilişkin olarak ortaya çıkar. Söz konusu çalışmaları gerçekleştiren bilim insanlarının çoğu elde edilen sonuçlara ulaşmak için sadece son teknolojiyle donatılmış beyin görüntüleme cihazlarından, bilimsel tekniklerden ya da kendi gözlemlerinden (kısaca üçüncül bakış açısından) yararlanmaz. Bu sonuçlara ulaşılmasında birinci elden hasta ve denek deneyimlerine başvurulur. Örneğin "hayalet uzuv fenomeni" hasta anlatıları yoluyla ortaya çıkar ve bu anlatılar beynin esnekliği ile ilgili

18 A.g.e., $11-15$

19 Maxine Sheets-Johnstone, The Primacy of Movement (Amsterdam / Philadelphia: John Benjamins Publishing Company,2011).

20 A.g.e., 187. 
çalışmaları güçlendirir. Ya da "sinestezi” fenomeni sesleri gördüğünü, sayıların ya da harflerin renkleri olduğunu ifade eden kişilerin deneyimleriyle beynin çapraz modellemesi ve yaratıcılık becerisi üzerine yapılan çalışmalara katkı sunar. ${ }^{21}$ Yani kısaca enaksiyon teorisi çerçevesinde yapılan bu bilimsel çalışmalar birincil deneyimin tüm gelişen teknolojik koşullara rağmen her zaman insan varoluşuna ilişkin en temel veri kaynaklarından biri olduğunu ortaya koyar ki bu da fenomenolojiyi bir yöntem olarak öne çıkarır. Bilindiği üzere fenomenoloji "tanımlanabilir deneyime" 22 ilişkin bir yöntemdir. Yani deneyimin kendisi bir araştırma konusu haline getirilir ancak fenomenolojik bir araştırmada deneyime birincil elden ulaşmak için bilimsel bilgi, kalıplaşmış yargılar ve ön kabuller askıya alınır. Tiyatro ve performans sanatları açısından da oyuncunun kendi birincil deneyimini bir öğrenme alanı olarak nasıl açacağı temel sorulardan biri haline gelir ki bu da aslında bir oyunculuk fenomenolojisinin mümkün olup olmadığı tartışmasını doğurur. Bu makalenin temel iddiası da somatik uygulamaların hareket araştırmaları yoluyla fenomenolojik olarak oyuncunun birincil deneyimi üzerine çalışması için bir yöntem önerisi olabileceğidir.

Enaksiyon teorilerinin ortaya koyduğu üçüncü önemli nokta beden fenomeninde yaşanan kaymaya ilişkindir. Bu kayma, yaşamı anlamlandırma süreçlerinde yukarıda vurgulandığı gibi hareketin ve birincil deneyimin öne çıkmasıyla ortaya çıkar. Beden artık kabaca karakterin üzerine giyilebileceği sadece bir mekan ya da ifade becerisini kuvvetlendirmek için eğitilmesi gereken bir gösteren olarak ele alınamaz. Çünkü bu bakış temelde Kartezyen ikiliğe dayalı temsil teorisinin sonuçlarıdır ve bedenin çok boyutluluğunu ve insanın anlam üretme mekanizmalarının bedenselliğini gözden kaçırır. Oysa Lakoff ve Johnson, Philosophy in the Flesh'de "bedenleşmiş gerçeklik (embodied reality)" kapsamında insan bedeninin beş farklı boyutunu dile getirir: Buna göre biyolojik bir organizma olarak beden dünyada olmamızın ilkesel fiziki mahalidir ve bilinç öncesi kapasiteleri (beden şemalarını ${ }^{23}$ ) vurgular; ekolojik beden devamlı süregelen organizma-çevre akışını içerir; fenomenolojik beden yaşadığımız, deneyimlediğimiz düşünümsel olarak kendimize dönük algılarımızı, tavırlarımızı ve inançlarımızı ifade eder; sosyal beden kişilerarası ilişkileri ve koordinasyon deneyimlerini içerir; kültürel beden ise bedenin kültürel yapılarla, uygulamalarla, kurumlarla, ritüellerle ve etkileşim yollarıyla şekillenip dönüşen boyutunu ifade eder. ${ }^{24}$ Kısaca, Johnson'ın iade ettiği gibi, insan bedeni terimini kullandığımızda merkezi odağımız daha çok elbette yaşayan biyolojik beden ve onu hissettiğimiz fenomenolojik

21 Bu iki örnekle ilgili daha ayrıntılı bilgiler için bkz Christian Keysers, Empatik Beyin: Ayna Nöronların Keşfi İnsan Doğasını Anlama Yetimizi Nasıl Değiştirdi?, çev. Ayber Eper (İstanbul: Alfa Yayınları, 2019); C. Sinigaglia, \& G. Rizzolatti, Beyindeki Aynalar: Zihinlerimiz Eylemleri ve Duyguları Nasıl Paylaşır?, çev. Devin Keleş (İstanbul: Alfa Yayınları, 2016); Merleau-Ponty, Algının Fenomenolojisi; V.S. Ramachandran, Öykücü Beyin, çev. Ayşe Cankız Çevik (İstanbul: Alfa Yayınları, 2016).

22 Shaun Gallagher ve Dan Zahavi, The Phenomenological Mind an Introduction to Philosophy of Mind and Cognitive Science (New York: Routledge, 2008), 5.

23 Beden şemasıyla ilgili bkz. Shaun Gallagher, How the Body Shapes the Mind, (NY: Oxford University Press, 2005)

24 Johnson, The Meaning of the Body: Aesthetics of Human Understanding, 275-277. 
bedenimizdir. Ancak insan bedeni bu beş boyutun tümüne de sahiptir; bir ya da birkaçına indirgenemez ${ }^{25}$. Öyleyse zihni bedenden, duyguyu akıldan, kültürü doğadan ayrı gören Kartezyen ikiliklerden artık uzaklaşıldığı aşikar hale gelir.

Ancak bedenleşme teorileri etrafında toplanan ve aslında bedenin yukarı da sıralanan çok boyutluluğunu içeren enaktif beden anlayışı teorik olarak yirmi birinci yüzyılın yaygın beden söylemi olarak kabul görse de bunun pratikteki karşılığını bulması o kadar kolay değildir. Çünkü Drew Leder'ın The Absent Body kitabında vurguladığı gibi, bedenli oluşumuz doğası gereği oldukça paradoksaldır. Yani bir yandan bedenli olmak, bu dünyadaki varoluşumuzun ön koşulu iken, bir yandan da deneyimlerimiz sırasında beden kendini unutturur ve Leder'ın deyişiyle "yoklukla (absent)" karakterize olur. Leder, örneğin günlük hayatta bir kitaba kendimizi kaptırmış okurken ya da son derece fiziksel olmasına rağmen hareketli bir biçim de sportif bir yarışın içinde odaklanmışken bedenimizin, deneyimimizin bir parçası değilmişçesine algımızdan kaybolduğunu dile getirir. Hatta dikkatimizi bedenimize verdiğimizde bile bedensel fonksiyonlarımızın işleyişinde bir problem yoksa (ağrıyan, kaşınan bir bölge vs.) bedeni bir bütün olarak algılayıp parçalarının tek tek farkına varmayız. ${ }^{26}$ Bedenin bu şekilde "algının odağından" kolaylıkla çıkmasının iki temel sebebi olduğu söylenebilir. İlk olarak bilişsel bilimler ve sinirbilimleri alanında yapılan çalışmaların ${ }^{27}$ tüm sonuçları bedensel organizasyonun, işlevlerini yerine getirirken işleyişinin çoğunu bilinç dışı düzeyde, tanımlanabilir deneyim alanının dışında gerçekleştirdiğini gösterir ki bu da bedenin biyolojik niteliklerine ilişkindir. Diğer taraftan da Kartezyen dünya görüşü, bilim dahil tüm kavramsal dünyamızın ve gündelik pratiklerimizin pek çoğunu domine ederek bedeni işleyen bir makina olarak görüp, aklı ya da "ruhu” ondan ayrı olarak ele alır. Bu durumda akıl "benliğin” esas özü olarak kabul görür, beden de nesneleştirilerek dünyadaki varlığımız için sadece bir aracı olma durumuna indirgenir. Böylelikle de bedenin sorunsuzca işlemesinin bir sonucu olan kendi işleyişini unutturma niteliği, Kartezyen düşüncenin ürettiği aracı beden nosyonuyla birlikte, bedenin "yokluğu" fikrini derinleştirir.

Tiyatro ve performans sanatları açısından düşünüldüğünde teoride kabul gören yaşayan bedenin çok boyutluluğunu gerçekten kavrayabilmek için de sıklıkla algının odağının dışına çıkan bu "görünmez bedeni”, sadece teoride değil uygulamada (fenomenolojik bir bağlamda) görünür kılmanın yollarını aramak gerekir. Bu anlamda da somatik yaklaşım Kartezyen bedeni

25 A.g.e., 278.

26 Drew Leder, The Absent Body (London: The University of Chicago Press, 1990),1-3.

27 Bu çalışmaların ayrıntıları için bkz. Nancy C., Andreasen Yaratıcı Beyin: Dehanın Nörobilimi, çev. Kıvanç Güney (Ankara: Akılçelen, 2019); Louise Barret, Beynin Ötesi, çev: İlkay A.Demir (İstanbul: Alfa Yayınları,2017); Daniel Dennett, Bilinç Açıklanıyor, çev. Sibel Kibar (İstanbul: Alfa Yayınları, 2017); Mark Johnson The Body In The Mind: The Bodily Basis of Meaning, Imagination, and Reason. Chicago (The University of Chicago Press, 1992). Keysers, Empatik Beyin: Ayna Nöronların Keşfi İnsan Doğasını Anlama Yetimizi Nasıl Değiştirdi?. 
değil, somayı yani Yunancadaki anlamıyla "kendi bütünlüğü içinde yaşayan beden" ${ }^{28}$ odağa alarak uygulamadaki bu açığı karşılar. Beden eğitimi pratiklerinde 70'li yıllardan itibaren bedenle ilgili bu kavrayış değişikliği fark edilmiştir aslında. Bunun sonucu olarak Thomas Hanna (1928-1990) sinirbilim ve tıp alanında yaptığı çalışmalar sonucunda beden kavramı yerine yeni bir kavramsallaştırma ihtiyacıyla yukarıda sayılan bedenin farklı nitelikleriyle ile uyumlu soma terimini önerir. ${ }^{29}$ Hanna'ya göre soma bir şey ya da nesnel bir beden değil, bir süreçtir; soma değişmez ya da sabit değildir, değişken ve esnektir. Soma, daima istikrar ve dengeye ulaşmaya çalışan bir sistem olarak oluşur ve bu görev zaman içinde gerçekleşir ama asla tamamlanmaz. Kendi dışsal aksiyonlarında olduğu gibi içsel işlevlerinde de soma, hareketlerini belli bir düzenle ölçüp koordine ederek kendini çevresine uyarlar. ${ }^{30} \mathrm{Bu}$ anlamda bu çalışmada konu edilen soma yaşayan bedeni biyolojik, ekolojik, sosyal, kültürel boyutlarıyla bütüncül bir biçimde bir süreç olarak ele alan bir kavrama karşılık gelir. Tüm bunlardan hareketle tiyatro ve performans sanatları açısından somatik yaklaşımı son dönemde elde edilen anlam, duygu, his, hafıza ve imgeleme ilişkin bilimsel verileri göz ardı etmeden (üçüncü kişinin bakışını) bedensel deneyime, birincil kişinin perspektifinden fenomenolojik bir refleksiyonla yaklaşarak tüm yaratıcı sürece yayılan harekete dayalı uygulama biçimleri öneren bir yaklaşım olarak kavramsallaştırabiliriz.

\section{Somatik Eğitimin Genel Özellikleri}

Son dönemlerde tiyatro ve performans sanatları eğitiminde (özellikle dans eğitimi alanında) sıklıkla yer bulan somatik uygulamalar temelde bireyin birincil hareket deneyimini odağa alan bir dizi hareket eğitimine verilen genel addır. Yoga, tai chi ve chi gong gibi daha geleneksel uygulamalardan Feldenkrais, Otantik Hareket, Laban/Bartenieff gibi 20. yüzyılda ortaya çıkan daha güncel çalışmalara, somatik şemsiyesi altında toplayabileceğimiz oldukça fazla zihinbeden uygulaması vardır. Bu tür uygulamalar iki ana dala ayrılır: biri masaj, kraniosakral terapi (bedensel denge terapisi), bedensel-duyusal rahatlama uygulamaları gibi daha pasif ve alıcl, diğeri de örneğin İdeokinesis, Alexander Tekniği, Feldenkrais Metodu, Laban/ Bartenieff Hareket Araştırmaları gibi daha aktif motor/hareket davranışları değiştirmek için katalizör olarak kişinin hareket farkındalığını ve imgelemini bilinçli olarak işbirliğine çağıran uygulamalardır. ${ }^{31}$ Genel olarak tiyatro, dans gibi performans sanatları eğitiminde daha çok yer verilen çalışmalar aktif olarak tarif edilen Feldenkrais, Alexander tekniği, Laban/Bartenieff hareket araştırmaları gibi uygulamalardır.

Çoğunlukla dans olmak üzere sanat eğitiminde imgelemi geliştirmek, yaratıcılı̆̆ sakatlığı önlemek gibi amaçlarla, klinik terapilerde ya da zaman zaman alternatif ya da

28 Thomas Hanna, The Body of Life: Creating New Pathways for Sensory Awareness and Fluid Movement (NY: Healing Arts Press, 1980), 8.

29 A.g.e., 8.

30 A.g.e., 6.

31 Glenna Batson, "Somatic Studies and Dance", International Association for Medicine and Dance, erişim: 10 Temmuz 2018, https://www.iadms.org/page/248. 
tamamlayıcı tedavi yöntemi olarak bazen de sadece kişisel farkındalık için kullanılan somatik eğitimler, öncelikli olarak diğer hareket eğitimlerinden felsefi temelleri ve temaları dolayısıyla ayrılır. Bu eğitimlerin felsefi temeli "kişisel otonomi arayışında zihin, beden ikiliğini ortadan kaldırmak"; en temel temaları da "öz farkındalık, öz kontrol, gelişim ve değişim için aktif katılıma istekli olma" olarak sıralanır. ${ }^{32}$ Burada sözü edilen "değişim ve gelişim için istekli olma" "33 aynı zamanda oyuncunun çalışmalar sırasındaki yönelimini ve tavrını belirlediğinden önemlidir. Her şeyden önce oyuncunun hareket deneyiminin kendisine görünür olması için fenomenolojik tavır gereklidir. Fenomenolojik tavır oyuncunun bilgilerini, beklentilerini, yargılarını askıya alması, o andaki odağının yönelimini fark etmesi, hareketinin etkisinin o an, o mekandaki koşullarla ilişkisini fark etmesini gerektirir. Bu da ancak istekli bir katılım koşuluyla gerçekleşebilir. Oyuncunun bu çeşit fenomenolojik tavrı olmaksızın da hareket deneyimi oyuncuya açılmaz. Bu nedenle temel temalar olarak tarif edilen öz-farkındalık ve öz-kontrol ancak gelişim ve değişim için aktif katılımla gerçekleşebilir. Bu niteliğiyle somatik hareket çalışmaları spor salonlarında ayna karşısında müzik eşliğinde yapılan egzersizlerden, eğitmenin adımlarının birebir kopyalandığı dans derslerinden ayrılır.

Örneğin Feldenkrais, Awarness Through Movement (Hareket Yoluyla Farkındalık) sistemi adını verdiği grup derslerinde genel olarak kaslardaki eforu azaltmak, değişimi fark edebilmek ve alışılagelmiş kassal örüntüleri kırmak için derslere yüzüstü ya da sırtüstü yatar pozisyonda başlandığını dile getirir. Ayak tabanlarında, eklemlerde alışılagelmiş baskı böylelikle önlenir. Sinir sistemi yerçekimi nedeniyle gönderilen alışılagelmiş uyaranları alamaz ve dönen uyaranlar da alışılagelmiş örüntüler içinde ilişkilendirilemez. Katılımcı dersten sonra tekrar eski alışılagelmiş uyaranı aldığında bu uyarana farklı tepki verdiğini keşfeder. Dersler mümkün olduğunca herhangi bir zorluk ya da acı olmadan yavaş ve keyifli yapılmaya çalışılır; ana hedef bilinen anlamıyla bedeni eğitmek değildir, kişinin kendi içinde bilmediği tepkileri keşfetmesi ve daha iyi ve uyumlu bir eyleme biçimini öğrenmesini sağlamaktır. Hareketler hafiftir, on beş ya da yirmi tekrardan sonra başlangıçtaki çaba neredeyse katılımcıyı pratikte hiç zorlamaz. $\mathrm{Bu}$ da kişide en yüksek düzeyde duyarlılığa sebep olur ve böylelikle kişi uyarılara verdiği tepkilerdeki en küçük değişiklikleri ve bedenin farklı bölgelerindeki hizalanmaları saptayabilir. Derslerin sonunda da katılımcı sadece bedenin çalışılan bölümlerinde değil bir bütün olarak hafifleme, yerle olan temasta rahatlama hisseder. Bu metot sadece kas ve iskelet sisteminde esneklik ve güçlenme gibi değişimlere yol açmaz aynı zamanda kişinin benlik imgesinde ve kişinin kendine olan yönelimindeki nitelikte de değişimlere yol açar. ${ }^{34}$

Benzer prensiplerle Bartenieff de kendi dersine katılan öğrencilerin diğer hareket derslerinden farklı keşiflerde bulunmaya yönlendirildiğini dile getirir. Örneğin Bartenieff

32 Deane Juhan, Job’s Body: A Handbook for Bodywork (NY: Station Hill Press, 1998).

33 A.g.e.

34 Moshe Feldenkrais, "Awarness Through Movement”, Embodied Wisdom The Collected Papers of Moshe Feldenkrais (California: North Atlantic Books, 2010), 69-75. 
bedeni çevreleyen alanın kollarla keşfedilmesi üzerine çalışan öğrencilerin özellikle bedenin arka bölümlerine ulaşmaya çalışırken belli bölgelere erişemediklerini, bazı pozisyonlarda sıkışıp kaldıklarını vs. ifade ettiklerini aktarır. Bartenieff böylesi durumlarda eğitmenin rotasyon gibi uzamsal elementleri kullanarak öğrencilerin kol hareketini yeni uzamsal olanaklara doğru yönlendirebilmesi gerektiğini ifade eder. Böylelikle öğrenci hareket sırasında sadece kas ve eklemlere (yani fleksiyon ve ekstensiyon) odaklanmak yerine aynı zamanda yeni bir uzamsal keşif sağlayan eklem dönüşlerine de odaklanabilir. Önemli olan kullanılmayan kas ve eklemlerin farkındalığını uyararak hareket olasılıklarını hem enerji hem de ifade gücü anlamında genişletmektir. ${ }^{35}$

Genel hatlarıyla bahsedilen bu iki örnekte görüldüğü gibi her bir somatik uygulama farklı odaklara sahip olsa da hemen hepsinin ortaklaştığı temel prensipler aynıdır. Dünya çapında pek çok somatik hareket pratiğini ve uygulayıcısını bir araya getiren Uluslararası Somatik Hareket Eğitimi ve Terapi Birliği (The International Somatic Movement Education and Therapy Association /ISMETA) somatik eğitimin katılımcılar açısından beş temel kazanımını aşağıdaki gibi tanımlar:

- "Bedene hem nesnel fiziksel bir süreç olarak hem de yaşayan bir bilincin öznel bir süreci olarak odaklanma,

- Homeostaziyi, ortak düzenlenmeyi ve nöraplastisiteyi (beynin esnekliğini) destekleyen algisal, kinestetik, öz-algısal (proprioceptive) ve iç-algısal (interoceptive) ${ }^{36}$ duyarlılĭgl gelişstirme,

- Çevreyle olan etkileşimde alışkanlığa dönüşmüş algısal, postural ve harekete ilişkin örüntüleri fark etme,

- Yapısal, işlevsel ve ifadesel entegrasyonu destekleyen hareket koordinasyonunu geliştirme,

- Bedensel olarak zindeliği deneyimlemek ve yaşam için anlam ve haz üretmeyi sağlama konularinda yardımcı olma"37

\section{Somatik Yaklaşımda Eğitim İçeriğinin Niteliği}

Gigi Berardi ise 2007 y1lında yayınlanan Mind Matters: Somatics is a Growing Trend in Dance Training adlı makalesinde somatik eğitimin üç anahtar kavramını özgün öğrenme içeriği, duyusal uyumlanma ve yoğunlaştırılmış dinlenme olarak tespit eder. ${ }^{38} \mathrm{Bu}$ tespitler somatik hareket eğitiminde ders içeriğinin ve öğrenme ortamının nasıl planlanması gerektiği

35 Irmgard Bartenieff ve Dori Lewis, Body Movement: Coping with the Environment (NY: Routledge, 1980), 229249.

36 Öz-algı (proprioception): Bedenin kaslarının ve eklemlerinin pozisyonu, yerini, hareketlerin uyumunu algılamamızı sağlayan duyu. Çoğunlukla alışkanlıklar, duyarsızlaşma ya da adaptasyon yüzünden farkında olmayız bu duyunun. İç-algı (interoception): Sekizinci duyu olarak ele alınır. Bedenin psikolojik ve fiziksel durumunu algılamamızı sağlar. Örneğin açlık ve susuzluğu iç-algı duyusu yoluyla hissederiz. StarInstitute, Your 8 Senses, erişim: 20.05.2019 https://www.spdstar.org/basic/your-8-senses\#f8.

37 "The International Somatic Movement Education and Therapy Association (ISMETA)", erişim 20 Nisan 2019 https://ismeta.org/about-ismeta/scope-of-practice.

38 Berardi G.'den aktaran Batson, "Somatic Studies and Dance". 
ile ilgili bize ip ucu vermesi açısından önemlidir. Batson, Berardi’nin tespit ettiği bu üç anahtar kavramı ayrıntılandırarak açıklar:

Özgün Öğrenme Iç̧eriği: Batson, somatik olarak oluşturulmuş bir öğrenme ortamının bedenin duyusal uyarıcılarına (nefese, kas gerilimine, bedenin zeminle yaptığı ilişkiye) odaklanabilmesi için öncelikle zihin-beden konuşmalarını (yani kişinin kendi iç sesini) sessizleştirerek başladığını dile getirir. Batson'a göre bu tür somatik öğrenme ortamlarında yarışmacı olmadan, kendini düzeltme stratejilerine başvurmadan, kişinin öz-kabulle kişisel keşiflerine odaklanılır. Katılımcılar hareketlerin doğru ya da ideal biçimlerini yapmaya çalışmak yerine, bedenselleşmiş bir kaynaktan yani hareket anında tamamıyla açık ve duyarlı olan bir kaynaktan hareket etmeyi öğrenirler. Bu çeşit bir eğitim katılımcıları katı engelleyici örüntülerden kurtarıp düşünceleri, duyguları ya da eylemleri kısıtlayan diğer sınırlardan kurtarmak için tasarlanmıştır. Batson, bu nedenle bu tür eğitimlerde duraklama anlarına ya da refleksiyona (düşünümselliğe) daha çok yer verildiğini böylelikle de katılımcıların bir amaca ulaşmak için efor harcanmayan bir atmosferde duyumsama ve hareket arasındaki süreyi uzatarak hareketsizlik ve hareket arasında duyusal geri bildirimleri keşfettiklerini dile getirir. ${ }^{39}$

Duyusal Uyumlanma: Batson somatik yaklaşımın motor eylemlerin ötesinde duyusal farkındalığa vurgu yaptığını dile getirir ve somatik öğrenme içeriğinde birinin nasıl hareket ettiğinin, hareketin ne olduğundan daha önemli olduğunun altını çizer. Ayrıca Batson katılımcılara içsel duyuları (sinirsel sinyalleri) keşfetme ve onları anlamlı kılma şansı verildiğinde bu "duyusal otoriteye" yani kişinin kendi yol göstericisine dönüşmesi ve öz kontrole sahip olması için temel bir dayanağa yol açtığını ifade eder. Duyusal otorite de hareket otonomisine (içsel olarak hareketin kişinin kendisi tarafından düzenlenmesi kapasitesi) ve hareketin öğrenilmesi sırasında yaygın dışsal referansların ayırt edilmesine (öğretmenin yönlendirmeleri, ayna ile çalışma gibi) ön ayak olur. ${ }^{40}$

Yoğunlaştırılmış Dinlenme: Somatik çalışmalar yoğun fiziksel aktiviteler üzerine kurulu olsa da sık sık aktiviteler arasında dinlenme anları kullanılır. Batson yüksek oranda dinlenme sürelerinin olmasının sinir sistemine işleme ve entegrasyon için, psikolojik sisteme de yeniden toparlanması ve kendine gelmesi için zaman verdiğini dile getirir. Ayrıca somatik dinlenme fazı fiziksel toparlanma için bir strateji olarak uygulanmaz yalnızca, aynı zamanda motor programlama için de uygulanır. ${ }^{41}$ Batson dinlenme sürelerinin hafızayı güçlendirmek (ne öğrenildiğinin hatırlanması) ve motor hatırlamayı (gerektiğinde öğrenileni geri çağırmayı) geliştirmek ve aynı zamanda gerçek performansı geliştirmek için de önemli olduğunu vurgular. Batson dinlenme sırasında temel sırt üstü dizler kırık uzanma pozisyonunun, yerçekiminin vücut

39 A.g.e., 2.

40 A.g.e., 2.

41 Richard Schmidt ve Tim Lee, Motor Control and Learning: A Behavioral Emphasis (NY: Human Kinetics, 2011). 
üzerindeki etkisini azalttığını ve kassal eforu ve postural desteğe dahil olan ekleme binen yükü en aza indirdiğini ifade eder. Böylece katılımcılar herhangi bir fiziksel efor göstermeksizin ders esnasında öğrenilenleri göz önüne getirerek nöromaskuler koordinasyonu arttırabilirler. Batson bunun için en az 10-20 dakikalık dinlenme periyotların önerildiğini de dile getirir."42

Batson'ın Berardi'den alıntılayarak açıkladığı somatik eğitimin bu üç anahtar kavramı somatik yaklaşımın oyunculukta, özellikle enaksiyon teorisi bağlamında neden önemli olduğunu da ortaya koyar. Bu üç niteliğin oyunculuk açısından önemini ayrıntılandırmaya çalışalım. Öncelikle bedenleşme teorileri çerçevesinde eğer birey kendi içinde bulunduğu fiziksel ve sosyokültürel çevresinden etkilenen ve kendisi de bu çevreler üzerine etki eden ve zihinsel şemaları (yani sinir haritaları da) bu etkileşimler yoluyla oluşan süreçler olarak tanımlanıyorsa bu evrensel bir ortaklığa işaret ettiği gibi bireysel özgüllüğün de altını çizer. Sinir bilimci Louise Barrett'ın da ifade ettiği gibi bedenleşme yaklaşımının özgürleştirici bir başka boyutu da davranışlarla ilgili bireysel farklılıklara yeni bir boyut kazandırmasıdır. Barret'a göre farklı bireylere ait davranış örüntüleri bu kişilere özgü bedensel dinamiklerin özgül çevrelerde gerçekleşmesiyle ortaya çıkar ve dolayısıyla o an ki çevresel koşullarla özgül bedensel yapı arasındaki etkileşimin sonucunda performansın değişkenliği bir zorunluluk ve sonuç olarak belirir. ${ }^{43}$ Bu nedenle somatik yaklaşımda katılımcıların gösterilen bir hareketi sadece düzgün yapmaya değil, daha çok hareketi yaparken kendi keşiflerine odaklanmaları bu özgüllüğe hizmet eder ve böylelikle özgün öğrenme içeriğiyle oyunculuk eğitimlerinde otantikliğe ve bireysel farklara yer açar.

Somatik eğitimlerin ikinci önemli niteliği olan duyusal öğrenmede oyunculuk çalışmaları açısından en önemli iddia bir önceki özgün öğrenme içeriğiyle de ilişkili olan "kişinin kendi yol göstericisine" dönüşmesidir. Enaksiyon teorileri bağlamında oyunculuğu ele aldığımızda (bu teorilerin beden-çevre etkileşimine yaptığı vurgu dolayısıyla) öne çıkan niteliklerden biri de mevcut çevresel koşullarda uygun tepkileri vermeye hazır olmadır. Bu durumda somatik çalışmalar sırasında katılımcıların oluşan tepkilerin duyusal dinamiklerini keşfetmeleri ve kendi hareket otonomileri üzerine çalışmalarının önemi ortaya çıkar. Moshe Feldenkraise 1988 yılında yayınladığ 1 Bodily Expressions adlı makalesinde somatik uygulamalar sırasında yapılan son derece kolay hareketlerde kaslarda hissedilen eforun gerçekte yapılan bir işin bir ölçüsü olmadığını, ancak hareketin nasıl organize olduğunun bir ifadesi olduğunu belirtir. Yani bu, hareketin niteliğine karşılık gelir. Zorluk derecesi farklı hareketler yaptığımızda yapılan işin niceliği değişebilir ancak o iş yapılırken bedenin tüm parçalarının organize olma biçimi değişmez yani nitelik aynı kalır. ${ }^{44}$ İşte somatik uygulamalar yoluyla hareketin temel niteliklerine ilişkin bu kavrayış, hareket otonomisini kazandıracak olan temel öğedir. Böylelikle oyuncu

42 Batson, "Somatic Studies and Dance", 3.

43 Barret, Beynin Ötesi, 219.

44 Moshe Feldenkrais, "Bodily Expressions", Embodied Wisdom The Collected Papers of Moshe Feldenkrais (California: North Atlantic Books, 2010), 12. 
en temelde bedensel organizasyonuna ilişkin geliştirdiği farkındalıkla koşullara uygun gerekli eforu (gücü) harcama becerisi kazanır ve bu eforu kontrol etmeyi öğrenmiş olur.

Berardi'nin somatik eğitimlerin üçüncü temel özelliğinden söz ederken yoğunlaştırılmış dinlenme olarak tarif ettiği özellik oyunculuk çalışmaları bağlamında düşünüldüğünde alternatif bir öğrenme biçimine karşılık gelir ve imgelemle motor beceri arasında ayna nöronlarının ${ }^{45}$ işleyişi dolayısıyla gerçekleşir. Hatırlanacağı üzere ayna nöronlar beynimizdeki motor nöronların sadece bir eylemi yaparken değil, aynı zamanda o eylemi hayal ederken, eylemin sesini duyduğumuzda ya da başkasının o eylemi yaptığını gördüğümüzde de ateşlendiğini ortaya koyar. Oyunculuk çalışmalarında imgelem daha çok hareket halinde oyuncunun karakteri yaratırken doğru evreni kurması için, ayrıntıları keşfetmesi için kullanılır. Ancak somatik çalışmalar kapsamında sıklıkla katılımcılar sadece dinlenme anlarında değil hareketleri yaparken de imgelemlerini kullanmaya teşvik edilirler. Böylelikle motor becerilerin yerleşmesi için tekrarın yanı sıra aktif imgelem beden imgesinin dönüşümü için kullanılmış olur.

Bir kez daha yenilemek gerekirse bedenleşme teorilerinden hareketle "bedensel kaynakların özgüllüğü kişiye özel öğrenme stratejileri ve gelişim yörüngeleri oluşmasını gerektirir." ${ }^{" 46} \mathrm{Bu}$ da somatik hareketin "öz-düzenleme, öz-sağaltım, kendini tanıma becerilerinin gelişimi için öğrencilerin/katılımcıların duyusal ve motor farkındalıklarını arttırma" ${ }^{47}$ olarak özetlenebilecek temel amacını bu çalışma açısından daha da önemli kılar. Çünkü somatik yaklaşımın kendi hedefini yerine getirebilmesi aynı zamanda öğrenme ortamının hatta yaratım esnasında prova sürecindeki ortamın düzenlenmesini de gerektirir. Burada kasıt elbette sadece fiziksel bir düzenleme değildir. Burada sözü edilen düzenleme duygusal olanı, zihinsel olandan, zihinsel olanı bedensel olandan, bedensel olanı yaratıcı olandan vs. ayıran dualistik bakışın terk edilmesidir. Bu konuda bu tür ikiliklerin duygusal olanın güçsüz olduğu, yöneticilikle ilgili işlerin daha zihinsel olduğu, kadınların daha çok duygularıyla hareket ettiği gibi ön yargılara sebep olduğu ve bu yargıların da prova ya da çalışma mekanında genel olarak oyunculara karşı davranışları ya da oyuncuların birbirine karşı davranışlarını etkilediğini belirten John Lutterbie'nin tespitleri oldukça yerindedir. Lutterbie, için ikilemin sürdürülmesi yaratıcı potansiyelin sınırlandırılmasıyla sonuçlanır. Bu bağlamda Lutterbie'nin öne sürdüğü gibi prova ya da çalışma mekanında bu yargıların dışarıda bırakılması için "çerçeveleme anlayışı" önemlidir. ${ }^{48} \mathrm{Bu}$ açıdan somatik yaklaşım sadece bir takım hareket dizilerini belli yönergelerle öğrencilerin uygulaması önerisinden çok, bu tür dualistik ikilemlerin ve bu ikilemlerin yol

45 Ayna nöronlarla ilgili ayrıntılı bilgi için bkz. Keysers. Empatik Beyin: Ayna Nöronların Keş̧i İnsan Doğasını Anlama Yetimizi Nasıl Değiştirdi? ; Ramachandran, Öykücü Beyin; Sinigaglia, ve Rizzolatti, G. Beyindeki Aynalar: Zihinlerimiz Eylemleri ve Duyguları Nasıl Paylaşır?.

46 Barret, Beynin Ötesi, 225.

47 Martha Eddy, "A Brief History Of Somatic Practices And Dance: Historical Development Of The Field of Somatic Education And its Relationship To Dance", Journal Of Dance And Somatic Practices (2009).

48 John Lutterbie, "Neuroscience and Creativity in the Rehearsal Process", Performance and Cognition: Theatre Studies and the Cognitive Turn, Ed. McConachie, Bruce; Hart, F. Elizabeth (NY: Routledge, 2006), 163. 
açtığı yargıların yaratıcı süreçte aşılması ihtiyacına da karşılık gelir. Bu nedenle bu yaklaşım hareket yoluyla "oyunculuğun ilişkisel, metaforiksel"49 ve hatta ilksel temellerine vurgu yapmayı hedefler.

Somatik yaklaşımla gerçekleştirilen hareket eğitimlerinin bu kazanımları oyunculuk yaklaşımında sözü edilen "bilinçli deneyime" ulaşılması için gereken kazanımları da ortaya koyar aynı zamanda. Burada tekrar vurgulanması gereken belki de en önemli şey somatik bakışın, bir fikir ya da teori olmasının ötesinde somatik uygulamalar olarak bilinen bir pratik dizi hareket eğitimini içerdiğinden tiyatro ve performans alanında kavram dünyasında yaşanan bilişsel kırılmanın sahneye sızması için bir uygulama alanı açıyor olmasıdır. Kısaca somatik çalışmalar sirasında oyuncu bilgiyi kendi hareket deneyiminde sınar. Burada aranan temel olarak soruya ilişkin alınan cevapların doğruluğu, yanlışlığı ya da tutarlılığı değildir. Önemli olan kişinin kendi deneyimine ilişkin araştırması boyunca soruların inceltilip yeni olanakları çağırması ve dolayısıyla bilginin olabildiğince kişileştirilip özgün yaratımlara zemin hazırlamasıdır. $\mathrm{Bu}$ nedenle somatik yaklaşım herhangi bir oyunculuk tekniğinden öte daha genel bağlamda (hem bireysel hem de kolektif anlamıyla) yaratıcılığın koşullarını sağlayan ve düzenleyen temel bir hazırlık süreci olarak da düşünülebilir.

\section{Somatik Hareketten Performans Farkındalığına}

Buraya kadar somatik pratiklerin ortak niteliklerini ayrıntılandırarak oyunculuk eğitiminde duyusal duyarlılığı geliştiren, yaratıcılığı ve özgüllüğü kışkırtan bir model olabileceğinden söz edildi. Bu bölümde de enaksiyon teorileri kapsamında değerlendirebileceğimiz hem deneysel hem de deneyimsel çalışmaların verilerinden yararlanarak somatik uygulamaların performatif bir beden farkındalığını nasıl geliştirebileceği anlaşılmaya çalışılacaktır. Ama öncelikle "performatif beden farkındalığı" kavramının oyunculuk açısından neye karşılık geldiğini farklı uygulamacılardan örneklerle anlamaya çalışalım.

On beşinci yüzyılda, Noh tiyatrosuna ilişkin en eski eğitim kitaplarından birinin yazarı olan oyuncu, eğitmen ve yönetmen Zeami Motokiyo, oyunculuğun dokuz farklı seviyesini tanımlarken oyuncunun erişebileceği en üst seviyeyi, "zihnin işlemlerinin ortadan kalktığ seviye" ${ }^{50}$ olarak tanımlar. Zeami'nin çalışmalarını anlattığı makalesinde Mark Nearman, bu seviyeyi tümüyle ustalık isteyen, oyuncuların tamamıyla kendiliğinden ve çabasız göründüğü ve seyircilerin oyuncunun oynadığının farkına dahi varmadığı bir seviye olarak ifade eder. ${ }^{51}$ Asya dövüş sanatları ve meditasyon teknikleri yoluyla psikofiziksel oyunculuk çalışmalarıyla tanınan Philip Zarilli ise bu seviyede oyuncunun farkındalığının “açık algısal bir farkındalık olduğunu

49 A.g.e., 164.

50 Mark J. Nearman, “Zeami’s Kyui. A Pedagogical Guide for Teachers of Acting”, Monumenta Nipponica, (1978), 324.

51 A.g.e. 
ve bunun da analitik, kavramsal bir idrak sürecinin tam tersini işaret ettiğini dile getirir. ${ }^{52}$ Çalışmalarında Stanislavski'nin izinden giden 1950'li ve 60'lı yıllarda Amerikan oyunculuk yönelimini belirleyen güçlü figürlerden biri olan Sanford Meisner ise kendi öğrencisiyle yaptığı konuşmayı şöyle aktarır:

Öğrenci: Hissi anlamaya başllyorum. Düşünme-yap!

Meisner: Bu çok iyi bir his. Tam da bir oyuncunun düşünme biçimi. Bir oyuncu nasıl düşünür? Düşünmez-yapar ${ }^{153}$

Başka bir örnekte de, Eugenio Barba Oyuncunun Gizli Sanatı: Tiyatro Antropolojisi adlı kitabında seyirciyle kurulan ilk iletişimi "anlatım öncesi” durum olarak tanımlar. Ona göre bir oyuncunun sahnede anlatımına geçmeden önceki "durumu” yani "anlatım isteği” seyircide anlık tepkilere sebep olur. Bu anlık tepkilere ön yorum adını veren Barba, izleyicinin bu ön yorumunun kültürel yorumdan önce geldiğini dile getirir. ${ }^{54}$ Oyuncunun sahne üzerindeki "halini" tarif eden farklı kültürler ve dönemlere ait tüm bu örneklerde iki temel nitelik ortaya çıkar. İlki ideal olarak usta bir oyuncunun sahne üzerinde özel bir bilinç seviyesini devreye sokması gerektiği, ikinci olarak da bu aşamanın tıpkı Barba'nın ifade ettiği gibi “anlatım öncesi”"55 ya da Zarilli'nin ifade ettiği "kavramsal seviyenin" 56 altında işleyen bir seviyeye karşılık geldiğidir. Usta oyuncuların erişmesi gerektiği düşünülen bu hal, sinirbilimi alanında yapılan deneysel çalışmalarla kişi deneyimlerine dayanan fenomenolojik çalışmaların sonuçlarını bir araya getiren araştırmacıların "performatif beden" ${ }^{57}$ ya da "performatif farkındalık" ${ }^{58}$ kavramlarıyla örtüşür.

Dorothee Legrand'ın kavramsallaştırdığg “performatif beden”, özel olarak bedene odaklanmaksızın bedenin ustalıkla işlediği özel bir haldir. ${ }^{59}$ Böyle anlarda ortaya çıkan farkındalığı Shaun Gallagher "performatif farkındalık" olarak ifade eder. ${ }^{60}$ Performatif beden ya da performatif farkındalık durumları bedenin deneyimimize, değişen biçimlerde dahil olabilmesi ve bunun sonucunda farklı seviyelerde işleyen bir beden bilincinin ortaya çıkması sayesinde gerçekleşir. Örneğin kadife bir kumaşa dokunduğumda ya da boynumu esnetmek için bilinçli olarak sağa sola çevirdiğimde bedenim farklı biçimlerde deneyime dahil olur.

52 Philip Zarrilli, “The Actor's Work on Attention, Awareness, and Active Imagination: Between Phenomenology, Cognitive Science, and Practices of Acting", Performance and Phenomenology Traditions and Transformations, Ed. Maaike Bleeker, Jon Foley Sherman, Eirini Nedelkopoulou (NY: Routledge, 2015), 77.

53 Meisner and Longwell'den aktaran Evelyn B. Tribble, "Distributed Cognition, Mindful Bodies and the Arts of Acting", Ed. R. Blair, A. Cook, \& N. Shaughnessy, Theatre, Performance and Cognition (Performance and Science: Interdisciplinary Dialogues) (London: Bloomsbury,2016), 133-141.

54 Eugenio Barba, Nicola Savarese, Oyuncunun Gizli sanatı: Tiyatro Antrololoji Sözlüğ̈̈, çev. Ayşin Candan (İstanbul: YKY, 2000), 62.

55 A.g.e., 62 .

56 A.g.e., 77.

57 Dorothee Legrand, "Pre-reflective self-consciousness: On being bodily in the World", Janus Head 9/2 (2007), 494-507.

58 Shaun Gallagher, "Theory, Practice and Performance”, Connection Science,29/1, (2016).

59 Legrand, "Pre-reflective self-consciousness: On being bodily in the World".

60 Gallagher, "Theory, Practice and Performance". 
Giovanna Colombetti The Feeling Body: Affective Science Meets the Enactive Mind adl makalesinde bedenin kadifeye dokunduğumuzda hissedilenin aracı olarak, kafamı sağa sola çevirdiğim durumlarda da doğrudan algı nesnesi olarak deneyime dahil olduğunu ifade eder. Böylelikle Colombetti iki tür bedensel bilinç tarif etmiş olur: bedenin algının yönelimsel nesnesi olmadan yani doğrudan bedenimize odaklanmadığımızda bile işleyen "ön-reflektif bedensel bilinç" ve doğrudan algımızı bedenimize yönelttiğimizde ortaya çıkan "reflektif bedensel bilinç". ${ }^{61}$ Performatif bedensel bilinç de doğrudan algımızın yönelimi bedenimizde olmaksızın ortaya çıktığı için ön-reflektif kendilik bilincinin özel bir formu olarak kavranır. ${ }^{62}$

Gallagher, Legrand, Montero, Toner ve Moran gibi araştırmacılar dansçılar, sporcular ve müzisyenlerle yaptıkları birbirinden farklı çalışmalarda performans anında ortaya çıkan bedensel farkındalıkla "ön-reflektif bedensel bilinç” arasındaki ilişkiye dair tutarlı sonuçlara varırlar. Bu çalışmalarda uzmanlık ve beceri isteyen eylemlerde ön-reflektif bedensel bilinç durumunun normal insanlardan daha farklı işlediği ortaya konur. ${ }^{63}$ Örneğin bir dansçı icra anında özel olarak bedeniyle ilgilenmek zorunda kalmadan bedenin varlığının ve eylemlerinin tamamıyla farkındadır ve bedenini kontrol edebilir ki bu, bedenin kendisi üzerine düşünülmediği ancak "bedenin kendisinin deneyimlendiği” anlara karşılık gelir. ${ }^{64} \mathrm{Bu}$ aşamada yukarıda da değinildiği gibi performatif beden devrededir; uzmanlaşmış kişi bedene özel olarak odaklanmaksızın gelişmiş ön-reflektif seviyede öz-algısal (proprioceptive) ve kinestetik duyular yoluyla bedeninin pozisyonlarının ve hareketlerinin duyusunun farkında olabilir. ${ }^{65}$ Yani tekrar vurgulanacak olursa k1saca performatif beden bilinci ön-reflektif bedensel bilincin özel bir formudur. ${ }^{66}$ $\mathrm{Bu}$ da doğrudan ön-reflektif bedensel farkındalığı somatik çalışmalarla ilişkilendirir. Çünkü hatırlanacağı üzere somatik çalışmaların en önemli iddialarından biri "algısal, kinestetik, özalgısal (proprioceptive) ve iç-algısal (interoceptive) duyarlılığ 1 geliştirme" ${ }^{97}$ olarak tanımlanmıştı. Bu durumda yukarıda da değinildiği gibi gelişmiş bir ön-reflektif bedensel bilinç, performatif farkındalığın ön koşulu ise doğrudan algı ve duyu duyarlılığını hedefleyen somatik yaklaşım oyuncular için performatif bir beden geliştirme yöntemi olarak öne çıkar.

Somatik uygulamalarda algısal yönelimin odağının gündeliğin dışında bir titizlikle harekete ilişkin niteliklere yönlendirilmesi oyuncunun ön-reflektif seviyenin yanı sıra reflektif seviyede de bedeniyle ilişkilenmesini sağlar. Oyuncunun yönelim, işlev ve ifadesellik arasındaki ilişkiyi araştıracağı bir alan yaratır. Burada basitçe hareket ederken bir yere yönelttiğimiz pasif bir dikkat söz konusu değildir. Hareket ederken, seçtiğim yönelim (farkında olarak ya da

61 Colombetti, The Feeling Body: Affective Science Meets the Enactive Mind, 115-117.

62 Legrand, "Pre-reflective self-consciousness: On being bodily in the World".

63 John Toner, Gail Montero Barbara ve Moran Aidan, "Reflective and Prereflective Bodily Awareness in Skilled Action", Psychology of Consciousness: Theory, Research, and Practice 3/4 (2016).

64 Legrand, "Pre-reflective self-consciousness: On being bodily in the World"

65 A.g.e.

66 A.g.e.

67 "The International Somatic Movement Education and Therapy Association (ISMETA)" 
olmayarak) hareketin anlamına katılır. Bu nedenle yönelim, işlev ve ifadesel olan arasındaki ilişki katılımcının “deneyim üzerine” bir refleksiyon (düşünüm) geliştirmesini değil, düşünüm ile eylemin birlikte oluştuğu bir "deneyim yaşamasını” sağlar ki bu da çalışma boyunca sıklıkla sözü edilen bedenleşmiş bir deneyime karşılık gelir. Somatik uygulamaların reflektif bedensel öz-farkındalık dışında, doğrudan bedene odaklanmadığımız zamanlarda bile kendisini gösteren, ön-reflektif seviyede bedensel bir öz-farkındalık kazandırmasının sebebi de çalışmalarda yönelim, işlev ve ifadesel olan arasındaki bu ilişkiyi katılımcı için hissedilir kılmasıdır.

Tüm bu bilgilerin 1şığında bu bölüm başında dile getirilen oyuncunun "zihnin işlemlerinin ortadan kalktığg1"68, "kendiliğinden ve çabası göründüğ̈̈"69, "düşünmeyip yaptı̆̆g”70 ve "anlatım öncesini" 71 de kapsayan halin performatif bedene ya da performatif farkındalığa karşılık geldiği söylenebilir. Ancak burada tarif edilen performatif beden bilinci, Meisner'in vurguladığı ve pek çok oyunculuk çalışmasında aşina olunan “düşünme, yap!” yönergesine yeni bir anlam kazandırır. Çünkü tıpkı doğu geleneğindeki meditasyon tekniklerinde ya da bilinçli farkındalık anlamına gelen "mindfulness" kavramında olduğu gibi eylemle yani yapma ile düşünümün birbirinden ayrılmadığı bir deneyimin imkanına işaret eder. Ancak somatik uygulamalar çoğu meditasyon tekniğinden farklı olarak oyuncunun doğrudan hareket üzerine çalışmasını sağlayarak pratik yoluyla hem reflektif seviye de hem de ön-reflektif seviyede bir beden bilinci geliştirerek oyuncuya bedenleşmiş bir deneyim için alan yaratır. Böylelikle oyuncu aklın tümüyle ortadan kalkmadığı, ama "eleştirel aklın devre dışı olduğu, tekniğinin de tamamen ortadan kaybolduğu"72 özel bir bilinç durumuna geçebilir.

\section{Sonuç}

Bugün geldiğimiz noktada hem deneysel hem de deneyimsel çalışmalar yaşanan deneyimin belirleyicisi olarak bize bilincin yönelimini işaret eder. Bu yönelimde algının odağı olsun ya da olmasın beden, değişen derecelerde deneyimde her zaman yer alır, hatta kendini en görünmezmiş gibi kıldığı durumlarda bile. Spor, müzik, dans ya da oyunculuk gibi (nitelikleri farklı olsa da) bedensel eğitime dayalı, sürekli tekrar yoluyla uzmanlaşma isteyen disiplinlerde kişiler, özellikle icra sırasında ortaya çıkan normal insanlardan farklı bir beden bilinci geliştirirler. Bu bilinç hali bedene doğrudan odaklanmayı gerektirmeyen, daha çok öz-alg1 (proprioception), kinestezi ve iç-algı (interoception) duyularının geliştirilmesiyle güçlenen ve bedenin bu yükseltilmiş duyarlılıkla deneyimlenmesini sağlayan bir bilince karşılık gelir. Bir oyuncunun da sahnede bedenini araçsallaştırmak yerine ustalık isteyen "bedenleşmiş bir oyunculuğa" ulaşabilmesi için ön-reflektif seviyedeki bedensel farkındalığını arttırması gerekir. Ancak sözü edilen türde bir

68 Nearman, “Zeami’s Kyui. A Pedagogical Guide for Teachers of Acting”, 324.

69 A.g.e.

70 Meisner and Longwell'den aktaran Tribble, "Distributed Cognition, Mindful Bodies and the Arts of Acting".

71 Barba ve Savarese, Oyuncunun Gizli sanatı: Tiyatro Antrololoji Sözlüğü, 62.

72 Zarrilli, "The Actor's Work on Attention, Awareness, and Active Imagination: Between Phenomenology, Cognitive Science, and Practices of Acting”, 77. 
farkındalığa ulaşmanın yolu sadece esneklik, kondisyon, güç üzerine yapılan fiziksel çalışmalar değildir. Bunun yolu yönelim, işlev ve ifadesel olan arasındaki ilişkiyi kavrayabilmekte; bu ilişkiyi optimum olacak şekilde koordine edebilmekte ve kişiselleştirebilmekte yatar.

Bugün daha çok nörofenomenoloji adı verilen alt disiplinin ilgi alanına giren kişinin birincil deneyimine ilişkin öz-gözlemsel yönelim çalışmalarının ya da enaktivist bilişsel bilimcilerin "bedenleşmiş bilinç” yaklaşımlarının kavramsallaştııılmalarından çok önce tiyatro dünyasındaki pek çok uygulamacının benzer bir bakış açısını benimsediğine dair örnekler bulunabilir. Örneğin Stanislavski'nin bir dönem yogayı çalışmalarında kullandığ $1^{73}$ ve oyuncunun psiko-fiziksel varlığı üzerine çalıştığı, Barba'nın bedensel çalışmaların yalnızca bireysel olabileceği ve bedenin içinde bulunduğu toplumsal koşullarla şekillendiği ${ }^{74}$, Grotowski'kinin çalışmalarını itki ile eylemin birlikte var olduğu ${ }^{75}$ fikri üzerine kurduğu biliniyor. Hatta Batı dişı tiyatro geleneklerinde Noh tiyatro oyuncusu ve eğitmeni Zeami ${ }^{76}$ örneğinde görüldüğü gibi, bugün bedenleşme denen yaklaşımın yüzlerce yıl önce oyuncunun kendini-izleme ve yükseltilmiş, duyarlı bir öz-farkındalık becerisi için, geleneksel meditasyon tekniklerinin kullanılması suretiyle benimsendiğine kaynaklarda rastlanır. O zaman burada yeni olan aslında yirminci yüzyılın bir icadı olarak somatik çalışmaların bilimsel çalışmaları ve fenomenolojiyi (yani Batı kültüründe deneyimden uzaklaşmaksızın bir kendi üzerine düşünmeyi mümkün kılan yöntemini) bir araya getirerek sahne sanatları için daha bilimsel temellere dayalı pratik bir alan açmasıdır. Somatik çalışmaların sunduğu bu pratik alan da her zaman sanatta geri dönülebilecek bir kaynak olarak yaratıcının deneyimini ve bu deneyime öz-düşünümsel bir geri dönüşün önemini ortaya koyar ve bunun nasıl yapılabileceğine ilişkin bilimsel bilgileri arkasına alan metotlar öne sürer. $\mathrm{Bu}$ metotlar da hareketin temel prensiplerine yaslanan metotlardir.

Somatik yaklaşım anlamın ve diğer bilişsel süreçlerin kurucu unsuru olarak öne çıkan hareketi odağına alan bir eğitim çalışması olması dolayısıyla, hem yaratım anında oyuncunun deneyiminin kendisine açılmasına olanak vererek yaratıcı süreci besler hem de performans anında tekniğin kaybolduğu, yükseltilmiş bir bilinç halini tarif eden performatif farkındalığg sağlar. Yani oyuncuyu düşünümsel bir somatik bilince ulaştırır. Bu yönüyle çağdaş sahne sanatlarının yeni arayışlarına yön verebilecek, kendini çevresiyle uyumlu ve çevresinden sorumlu yaratıcı failler olarak gören oyuncular yetiştirmek için alternatif bir eğitim olanağı sunar.

73 Rose Whyman, Oyunculukta Stanislavski Sistemi:Modern Performans Alanındaki Mirası ve Etkisi, çev. Hakan Gür (İstanbul: Dost, 2012).

74 Barba ve Savarese, Oyuncunun Gizli Sanatı: Tiyatro Antrololoji Sözlüğü, 80.

75 Grotowski, Yoksul Bir Tiyatroya Doğru, 3.

76 Bkz. Nearman, “Zeami’s Kyui. A Pedagogical Guide for Teachers of Acting”. 
Peer-review: Externally peer-reviewed.

Conflict of Interest: The author has no conflict of interest to declare.

Grant Support: The author declared that this study has received no financial support.

Hakem Değerlendirmesi: Dış bağımsız.

Çıkar Çatışması: Yazar çıkar çatışması bildirmemiştir.

Finansal Destek: Yazar bu çalıșma için finansal destek almadığını beyan etmiștir.

\section{KAYNAKÇA / BIBLIOGRAPHY}

Andreasen, Nancy C. Yaratıcı Beyin: Dehanın Nörobilimi, çev. Kıvanç Güney. Ankara: Akılçelen, 2019.

Barba, Eugenio, ve Nicola Savarese. Oyuncunun Gizli Sanatı: Tiyatro Antropoloji Sözlüğü, çev. Ayşın Candan. İstanbul: YKY,2000.

Barret, Louise. Beynin Ötesi, çev. İlkay A. Demir. İstanbul: Alfa, 2007.

Bartenieff, Irmgard, ve Dori Lewis. Body Movement: Coping with the Environment. NY: Routledge, 1980.

Batson, Glenna. "Somatic Studies and Dance”. Erişim: 10 Temmuz 2018 https://www.iadms.org/page/248.

Bumin, Tülin. Tartışılan Modernlik: Descartes ve Spinoza. İstanbul: YKY, 2019.

Colombetti, Giovanna. The Feeling Body: Affective Science Meets the Enactive Mind. Cambridge: MIT Press. 20014

Damasio, Antonio. Descartes 'in Yanılgısı: Duygu, Akıl ve İnsan Beyni. çev. Bahar Atlamaz. İstanbul: Varlık Bilim, 2006.

Descartes. Meditasyonlar: Metafizik Üzerine Düşünceler, çev. Çiğdem Dürüşken, İstanbul: Alfa Yayınları, 2019.

Eddy, Martha. "A Brief History Of Somatic Practices And Dance: Historical Development Of The Field of Somatic Education And its Relationship To Dance.” Journal Of Dance And Somatic Practices, 2009.

Edmund Husserl, Fenomenoloji Üzerine Beş Ders, çev. Harun Tepe. Ankara: Bilgesu Yayıncıl1k, 2015.

Moshe Feldenkrais, "Bodily Expressions", Embodied Wisdom The Collected Papers of Moshe Feldenkrais. California: North Atlantic Books, 2010.

Moshe Feldenkrais, "Awarness Through Movement", Embodied Wisdom The Collected Papers of Moshe Feldenkrais. California: North Atlantic Books, 2010.

Fischer-Lichte, Erica. Performatif Estetik. çev: Tufan Acil. İstanbul: Ayrıntı, 2004.

Gallagher, Shaun. How the Body Shapes the Mind. NY: Oxford University Press, 2005.

Gallagher, Shaun. "Phenomenological And Experimental Contributions To Understanding Embodied Experience" Body, Language and Mind: Voll: Embodiment, Ed. Tom Ziemke, Jordan Zlatev ve Roslyn M. Frank, 271-280. Berlin: De Gruyter, 2007.

Gallagher, Shaun. "Theory, Practice and Performance”. Connection Science. 2006.

Gallagher, Shaun, ve Dan Zahavi. The Phenomenological Mind an Introduction to Philosophy of Mind and Cognitive Science. New York: Routledge, 2008.

Gare, Arren. "The Grand Narratıve Of The Age Of Reembodıments: Beyond Modernısm And Postmodernısm" Cosmos and History: The Journal of Natural and Social Philosophy 9/1, 327-357, 2003. 
Green, Jill. "Somatic Knowledge: The Body as Content and Methodology in Dance Education" Journal of Dance Education, 18 March: 114-118, 2011.

Grotowski, Jerzy. "Yoksul Bir Tiyatroya Doğru”, Yoksul Bir Tiyatroya Doğru, çev. Osman Akınhay, İstanbul: Agora. 2016.

Hackney, Peggy. Making Connections: Total Body Integration Through Bartenieff Fundemantals. NY: Routledge.2002.

Hanna, Thomas. Somatics: Reawakening the Mind's Control of Movement. Cambridge: Da Capo Press.1988.

Hanna, Thomas. The Body of Life: Creating New Pathways for Sensory Awareness and Fluid Movement. New York: Healing Arts Press. 1980.

Harvie, Jen. Making Contemporary Theatre: International Rehearsal Processes, Manchester: Manchester Universty Press, 2010.

Jay, Martin. Deneyim Şarkıları, çev. Barış Engin Aksoy. İstanbul: Metis, 2012.

Johnson, Mark. The Meaning of the Body: Aesthetics of Human Understanding. Chicago: University of Chicago Press. 2007.

Johnson, Mark. The Body in The Mind: The Bodily Basis of Meaning, Imagination, and Reason. Chicago: The University of Chicago Press, 1992.

Juhan, Deane. Job’s Body: A Handbook for Bodywork. NY: Station Hill Press. 1998

Keysers, Christian. Empatik Beyin: Ayna nöronların keşfi insan doğasını anlama yetimizi nasıl değiştirdi?, çev. Ayber Eper. İstanbul: Alfa Yayınları, 2019.

Lakoff, George, and Johnson Mark. Philosophy in The Flesh: The Embodied Mind And Its Challenge to Western Thought. NY: Basic Books. 1999.

Leder, Drew. The Absent Body. London: The University of Chicago Press. 1990.

Legrand, Dorothee. "Pre-reflective self-consciousness: On being bodily in the World" Janus Head 9/2, 493519. 2007.

Lehmann, Hans-Thies. Postdramatic Theatre. Çeviren Karen Jürs-Munby. NY: Routledge. 2006.

Lutterbie, John. "Neuroscience and Creativity in the Rehearsal Process". Performance and Cognition: Theatre Studies and the Cognitive Turn içinde, Ed. Bruce McConachie ve F. Elizabeth Hart. NY: Routledge. 2006.

Merleau-Ponty, Maurice. Algının Fenomenolojisi, çev. Emine Sarıkartal, İstanbul: İthaki Yayınları, 2016.

Montero, Barbara Gail. "Thinking In The Zone: The Expert Mind In Action." The Southern Journal of Philosophy 53, 126-140. 2015.

Nearman, Mark J. “Zeami’s Kyui. A Pedagogical Guide for Teachers of Acting.” Monumenta Nipponica 33, 299-332. 1978.

Pavis, Patrice. Contemporary Mise En Scène: Staging Theatre Today, çev. Joel Anderson. London/New York: Routledge, 2013.

Peirce, C. S., James, W. \& Dewey, J. Felsefenin Yeniden Yapılandırlmasl, Pragmatizm: Pratik Bir Felsefe Seçme Yazılar, çev. ve Ed. Sarah Çelik, İstanbul: Doruk Yayımcılık, 2018.

Ramachandran, V.S. Öykücü Beyin, çev. Ayşe Cankız Çevik. İstanbul: Alfa Yayınları, 2016.

Schmidt, Richard ve Lee, Tim. Motor Control and Learning: A Behavioral Emphasis. NY: Human Kinetics. 2011.

Seigel, Jerrold. The Idea of the Self: Thought and Experience in Western Europe since the Seventeenth Century. NY: Cambridge University Press. 2005. 
Bedenleşme ve Enaksiyon Teorilerinin Çağdaş Tiyatro Uygulamalarına Yansımaları: Oyunculuk Eğitiminde...

Sheets-Johnstone, Maxine. The Primacy of Movement. Amsterdam / Philadelphia: John Benjamins Publishing Company. 2011.

Shusterman, Richard. "Body Consciousness and Performance: Somaesthetics East and West" The Journal of Aesthetics and Art Criticism 67/2, 133-145, 2009.

Sinigaglia, Corrado, ve Giacomo Rizzolatti, Beyindeki Aynalar:Zihinlerimiz Eylemleri ve Duyguları Nasıl Paylaşır?, çev. Devin Keleş İstanbul: Alfa Yayınları, 2016.

Star Institute, Your 8 Senses, erişim: 20.05.2019 https://www.spdstar.org/basic/your-8-senses\#f8.

The International Somatic Movement Education and Therapy Association (ISMETA) Erişim: 04.01.2019, https://ismeta.org/about-ismeta/scope-of-practice .

Toner, John., Montero Barbara Gail, ve Moran Aidan. "Reflective and Prereflective Bodily Awareness in Skilled Action" Psychology of Consciousness: Theory, Research, and Practice 3/4, 303-315, 2016.

Tribble, Evelyn B. "Distributed Cognition, Mindful Bodies and the Arts of Acting”, Ed: R. Blair, A. Cook, \&N. Shaughnessy, Theatre, Performance and Cognition (Performance and Science:Interdisciplinary Dialogues). London: Bloomsbury,2016.

Varela, Francisco; Rosch, Eleanor, ve Thompson, Evan. The Embodied Mind: Cognitive Science and Human Experience. Massachusetts: MIT Press. 1991.

Whyman, Rose. Oyunculukta Stanislavski Sistemi:Modern Performans Alanındaki Mirası ve Etkisi, çev. Hakan Gür. İstanbul: Dost. 2012.

Zahavi, Dan. Husserl'in Fenomenolojisi, çev. Seçim Bayazit. İstanbul: Say Yayınları. 2018. 